\title{
The Influence of Gender on Conflict Management Styles: A Study among Employees of Public Banks in Ethiopia
}

\author{
Asemamaw Tilahun Debas ${ }^{1}$, E. A. Narayana ${ }^{2}$ \\ ${ }^{1}$ Andhra University, Department of Political Science \& Public Administration, Visakhapatnam, India \\ ${ }^{2}$ Professor, Andhra University, Department of Political Science \& Public Administration, Visakhapatnam, India
}

\begin{abstract}
The objective of this exploratory study is to determine the influence of gender on conflict management styles of employees of Public Sector Banks in Ethiopia. The study identified gender as independent variable and conflict management styles of avoiding, compromising, dominating, integrating and obliging as dependent variables. Using Rahim's Organizational Conflict Inventory (ROCIII) instrument, survey data were collected from 301 employees working in Ethiopian public banks. The result indicates that gender had a significant impact on the compromising and integrating conflict management style preference of employees, meanwhile, these differences could not be found for avoiding, dominating and obliging conflict handling styles. This study has given a more usable picture of the impact of gender on conflict management styles.
\end{abstract}

Keywords: Gender, Conflict management, Public banks, Interpersonal Conflict

\section{Introduction}

Conflict is an inevitable and common issue in our daily lives. Caused by disagreements in goals, motivations, communication problem or some other factors between two parties that can be real or perceived to exist, conflict is seen as a perceived incongruity of interests [1]. Whether it results because of a dissimilarity of beliefs, cruel words or direct action to settle contending objectives, conflict can possibly happen in numerous areas of our lives. According to Coser, conflict is thought to be the common and inescapable result of social and organizational life [2]. Mayer claims further that conflict is normal, natural, necessary and the problem is not the existence of conflict but how we handle it [3]. Organizational conflict is common in the workplace because people always have divergent opinions on several subjects, interests, beliefs, objectives, and interests.

Different scholars defined conflict in different ways. Rahim defined conflict as an "interactive process manifested in incompatibility, disagreement, or dissonance within or between social entities" [4]. Roloff further defined conflict as "organizational conflict occurs when members engage in activities that are incompatible with those of colleagues within their network, members of other collectivities or unaffiliated individuals who utilize the services or products of the organization" [5].

Conflict normally has been seen as a sign of organizational and interpersonal dysfunction. For example, Mayo asserts that organizations should try to avoid conflict as much as possible [6]. The human relation movement also believes conflict must be purged from the organizational setting [7]. In recent years, however, perceiving of conflict as dysfunctional and avoidable is changing. There are conflict theories, who believe that some amount of interpersonal conflict is necessary within organizations [8], [9], [10].
Deutsch claims that "conflict is often part of the process of testing and assessing one's self and as such, may be highly enjoyable as one experiences the pleasure of full and active use of one s capacities" [11]. This interest shows conflict is part of the organizations daily activities and the work should focus on how to manage it.

There are different causes for conflict to occur within an organizations such as personal differences, lack of rationalization in decision making, communication problems, etc [12], [13], [14]. Since conflict is common and inevitable aspects of organizational activities, conflict management within an organizations is a big topic that receives a significant attention in the academic literatures and working environments [15], [16], [4], [17] [14].

According to Rahim, "Organizational conflict may be classified as intra-organizational (i.e., conflict within an organization) or inter-organizational (i.e., conflict between two or more organizations). Intra-organizational conflict may also be classified on the basis levels (individual, group, etc.) at which it occurs. On this basis, intra-organizational conflict may be classified as intrapersonal, interpersonal, intra-group, and intergroup" [4]

In order to solve organizational conflict, different models have been developed by different scholars. The model of conflict management styles initially presented by Blake and Mouton [18] and further developed by Thomas and Kilmann [19], and Rahim [20] identifies the following five conflict handling styles. However, among the conflict management models, Rahim "s organizational conflict inventory (ROCI-II) is the most popular and widely used. Rahimes model of handling conflict varies according to two basic dimensions: "concern for self" and "concern for others." These dimensions incorporate five conflict management styles. These styles are integrating, compromising, avoiding, dominating and obliging. The integrating style refers to high

\section{Volume 5 Issue 3, March 2016}




\section{International Journal of Science and Research (IJSR) \\ ISSN (Online): 2319-7064}

Index Copernicus Value (2013): 6.14 | Impact Factor (2014): 5.611

concern for self as well as the other party involved in the conflict. It involves collaboration between parties. The obliging/accommodating style refers to low concern for self and high concern for others. It is concerned with smoothing over differences and focusing on areas of agreement. The dominating/competing style involves a high concern for self and a low concern for the other party involved in the conflict. It has been described as forcing one's viewpoint at the expense of others. The avoiding style involves low concern for self as well as the other party. It is concerned with withdrawing from the conflict situation. The compromising style refers to moderate concern for self as well as the party involved in the conflict. It is concerned with give-and-take or sharing the search for a middle-ground solution.

Conflict management is a very important skill within an organization to achieve the organization,,s objectives and goals. With the increase in the number of women 's moving into organizations, the possible effect of gender differences in the ability to manage conflict comes to mind [21]. However, the literature on the conflict handling styles of males and females is inconsistent. For example, in a study of Singaporean managers by McKenna and Richardson, men were found to use the compromising style more than women, while women were more inclined to use the avoiding style [22]. While Rahim (1983) found that women were more likely to use obliging and integrating than men [20]. Bedell and Sistrunk suggested that women were more competitive [23]. On the other hand, some research suggests that males and females occupying similar positions behave in much the same way in managing conflict [24]; [25]; [21]. Some research, on the other hand, suggests that women have a more cooperative approach to conflict than men [20]; [26]. In a study conducted by Green et al., it was found that conflict management styles differed according to biological sex and gender role. The feminine group used more avoiding styles compared to male and androgynous groups, whereas male groups tend to be more dominating [27].

The above discussion shows that the influence of gender on conflict management style has yielded inconsistent results. This study will look at the relationship between gender and conflict management styles, a topic that has inconsistent results, in order to develop a deeper understanding of organizational conflicts.

The study selected Ethiopian public sector banks employees as a place of study because the financial business would be the anchor regarding just about any economic system. Development regarding just about any country is straight or perhaps ultimately motivated through soundness of the banking system of the country. In order to function the banking industry well, interpersonal relations of the organization needs attention. Conflict management is one of such issues. Second, the study of the influence of gender on conflict management styles among employees of public sector banks in Ethiopia has not yet been studied and put to public consumption.

The main problem addressed by this research, therefore, is to determine the influence of gender on conflict management styles of employees of public sector banks in Ethiopia.

\section{Research Questions}

For the purpose of this study, the following research questions have been asked.

1) Are there meaningful differences among employees ${ }^{\text {ee }}$ avoiding conflict management styles related to their gender?

2) Are there meaningful differences among employees ${ }^{\text {ee }}$ compromising conflict management styles related to their gender?

3) Are there meaningful differences among employees ${ }^{\text {ce }}$ dominating conflict management styles related to their gender?

4) Are there meaningful differences among employees ${ }^{\text {ee }}$ integrating conflict management styles related to their gender?

5) Are there meaningful differences among employees ${ }^{\text {ee }}$ obliging conflict management styles related to their gender?

\section{Hypothesis}

Based on the existing inconsistent theories of the relationship between gender and conflict management styles, the following hypothesis is formulated:

1)There is no a statistically significant difference on the avoiding conflict management style used by employees on the basis of gender in public banks in Ethiopia.

2)There is no a statistically significant difference on the compromising conflict management style used by employees on the basis of gender in public banks in Ethiopia.

3)There is no a statistically significant difference on the dominating conflict management style used by employees on the basis of gender in public banks in Ethiopia.

4)There is no a statistically significant difference on the integrating conflict management style used by employees on the basis of gender in public banks in Ethiopia.

5)There is no a statistically significant difference on the obliging conflict management style used by employees on the basis of gender in public banks in Ethiopia.

\section{Research Methodology}

\subsection{Research Design}

The study utilized a quantitative approach of a nonexperimental - survey research design. Survey design was used because the researcher can gather accurate information about a large number of people using a small sample and the objective of the study dictates to use it.

\subsection{Population}

The population of the study was employees from three public sector banks in Ethiopia. These three banks are Commercial Bank of Ethiopia, Development Bank of Ethiopia and Construction \& Business Bank. The total number of employees of each bank was 18,000, 900 and 1,539 respectively as of December 31, 2012 [28]. 


\section{International Journal of Science and Research (IJSR) \\ ISSN (Online): 2319-7064 \\ Index Copernicus Value (2013): 6.14 | Impact Factor (2014): 5.611}

\subsection{Sample size and sampling techniques}

A proportionate simple random sampling technique was used to select the appropriate size of employees from each bank. The sample size was determined based on Yemane's formula [29]. Based on the formula, a total of 392 employees were selected.

\subsection{Instrument}

Employees of public sector banks in Ethiopia were surveyed using Rahim Organizational Conflict Inventory- II (ROCI-II) developed by Rahim [20]. This instrument consists of 28 statements and a five-point Likert scale was used to score each statement with a 5 indicating strongly agree and 1 a strongly disagree. In addition to the items from ROCI-II, demographic characteristics were also collected from the participants. The survey instruments were distributed to employees at their workplace. The data were collected from employees who were employed during the 2014-2015 fiscal years. The researcher sets the predetermined response rate for distributed surveys at $60 \%$; however, $77 \%$ of the survey packets were returned. Reliability and validity of the instrument was checked to assess the quality of the instrument.

The reliability of the instrument was assessed with Cronbach's alpha. The result shows that integrating, obliging, dominating, and compromising have reasonable internal consistency reliability of $0.833,0.741,0.793$, and 0.703 respectively. However, 0.694 alpha value of the avoiding scale indicated minimally adequate reliability.

The convergent and discriminatory validity of the instrument was confirmed by several earlier studies. The result of these validities together with the evidence reported in other field supported the instruments construct validity [4].

\subsection{Variables of the study}

The research aims to find out whether gender has a significant influence on the choice of conflict management styles of employees. The independent variable of the study was gender and the dependent variables were conflict management styles of employee"s i.e., avoiding, compromising, dominating, integrating and obliging.

\subsection{Data analysis}

The collected data were analyzed using Statistical Package for the Social Sciences (SPSS) version 20.0, a statistical software program. Descriptive statistics and independent sample t-test were utilized to analyze the data.

\section{Findings of the Study}

\subsection{Demographic data}

The important demographic characteristic of the study is employees $^{\text {ee }}$ gender. This demographic data was reported with frequencies and percentages. Table 1 shows the frequencies and percentages of gender of employees.

Table 1: Gender Profile of employees

\begin{tabular}{|c|c|c|}
\hline Gender & Frequency & Percentage \\
\hline Male & 163 & 54.2 \\
\hline Female & 132 & 43.9 \\
\hline Didne $^{\text {ee }}$ respond & 6 & 2 \\
\hline Total & 301 & 100 \\
\hline
\end{tabular}

Note: All gender questions were not completed for each respondent.

As shown in the above table 1 , among the total respondents ( $f$ $=301)$, 54.2\% $(f=163)$ were male and $43.9 \%(f=132)$ were female. Only $6(2 \%)$ of the respondents did not report gender. From this we can conclude that the majority of employees of Ethiopian public sector banks were male.

\subsection{Gender and Conflict Management Styles}

The hypothesis sought to determine if differences existed on the preference of conflict management styles with regard to gender. Independent sample t-test was determined for each of the five conflict management styles.

Hypothesis: There is no a statistically significant difference in the preference of conflict management styles of avoiding, compromising, dominating, integrating and obliging on the basis of gender as measured by the ROCI-II of employees of Public Sector Banks in Ethiopia.

The summary of descriptive statistics is given in Table 2 and the results for the independent sample t-test are given in Table 3.

Table 2: Summary statistics for gender and conflict management styles

\begin{tabular}{|c|c|c|c|c|c|}
\hline Styles & Gender & $N$ & Mean & $S D$ & Std.Error \\
\hline \multirow{2}{*}{ Avoiding } & Male & 163 & 3.336 & .786 & .061 \\
\cline { 2 - 6 } & Female & 132 & 3.328 & .736 & .064 \\
\hline Compromising & Male & 163 & 3.746 & .783 & .061 \\
\cline { 2 - 6 } & Female & 132 & 3.534 & .757 & .065 \\
\hline \multirow{2}{*}{ Dominating } & Male & 163 & 3.166 & .977 & .076 \\
\cline { 2 - 6 } & Female & 132 & 2.995 & .877 & .076 \\
\hline Integrating & Male & 163 & 4.122 & .683 & .537 \\
\cline { 2 - 6 } & Female & 132 & 3.906 & .740 & .064 \\
\hline \multirow{2}{*}{ Obliging } & Male & 163 & 3.379 & .778 & .060 \\
\cline { 2 - 6 } & Female & 132 & 3.358 & .742 & .064 \\
\hline
\end{tabular}

Table 2 shows the summary statistics of gender and conflict management. As the table shows, on average, male employees mostly use conflict management styles of integrating $(M=4.122, S E=0.537)$, followed by compromising $(M=3.746, S E=0.061)$, obliging $(M=3.379$, $S E=0.060)$, avoiding $(M=3.336, S E=0.061)$ and dominating $(M=3.166, S E=0.076)$. Similarly, female employees mostly use conflict management styles of integrating $(M=3.906, S E=0.064)$, followed by compromising $(M=3.534, S E=0.065)$, obliging $(M=3.358$, $S E=0.064)$ avoiding $(M=3.328, S E=0.064)$ and dominating $(M=2.995$, $S E=0.076)$. 


\section{International Journal of Science and Research (IJSR) \\ ISSN (Online): 2319-7064}

Index Copernicus Value (2013): 6.14 | Impact Factor (2014): 5.611

Table 3: Summary of Independent Sample t-test of conflict management style with regard to gender

\begin{tabular}{|c|c|c|c|c|c|c|c|}
\hline & \multirow[t]{2}{*}{ Variables } & \multicolumn{2}{|c|}{$\begin{array}{c}\text { Levene's Test } \\
\text { for Equality of } \\
\text { Variances }\end{array}$} & \multicolumn{4}{|c|}{ t-test for Equality of Means } \\
\hline & & $F$ & Sig. & $t$ & $d f$ & $\begin{array}{l}\text { Sig. (2- } \\
\text { tailed) }\end{array}$ & $\begin{array}{c}\text { Mean } \\
\text { Difference }\end{array}$ \\
\hline \multirow[b]{2}{*}{ Avoiding } & Equal variances assumed & 1.493 & 0.223 & 0.091 & 293 & 0.928 & 0.00812 \\
\hline & Equal variances not assumed & & & 0.091 & 286.8 & 0.927 & 0.00812 \\
\hline \multirow[b]{2}{*}{ Compromising } & Equal variances assumed & 0.168 & 0.682 & 2.355 & 293 & $.019 *$ & 0.21284 \\
\hline & Equal variances not assumed & & & 2.363 & 283.89 & 0.019 & 0.21284 \\
\hline \multirow[b]{2}{*}{ Dominating } & Equal variances assumed & 0.522 & 0.471 & 1.568 & 293 & 0.118 & 0.17142 \\
\hline & Equal variances not assumed & & & 1.586 & 289.88 & 0.114 & 0.17142 \\
\hline \multirow[b]{2}{*}{ Integrating } & Equal variances assumed & 1.101 & 0.295 & 2.596 & 293 & $.010 *$ & 0.21577 \\
\hline & Equal variances not assumed & & & 2.574 & 270.24 & 0.011 & 0.21577 \\
\hline \multirow[b]{2}{*}{ Obliging } & Equal variances assumed & 0.963 & 0.327 & 0.232 & 293 & 0.816 & 2076 \\
\hline & Equal variances not assumed & & & 0.234 & 285.15 & 0.815 & 0.02076 \\
\hline
\end{tabular}

Note: *Significant @ $p \leq 0.05$. The effect sizes for significant variables were compromising (0.13) and integrating (0.15). Threshold for interpreting the effect size can be found in Cohen's test. [30]. Cohen classified effect size that small (0.20), medium (0.50), and large (0.80).

Where the Levene's test of equality of variances have been found significant $(p<0.05)$, row with equal variances not assumed is notified and where variances have not been significant, equal variances assumed row is notified. In the above table 3, Levene"s test is not significant; therefore, we should read the test statistics in the row labeled Equal variances assumed.

As the table above shows, independent sample t-test was conducted to explore the impact of gender on the preference of conflict management styles as measured by Rahim Organizational Conflict Inventory (ROCI-II). The test shows that a statistically significant result have been found for compromising $t(293)=0.019, p \leq .05$ and integrating $t(293)$ $=0.10, p \leq .05$ conflict management styles. Therefore, we reject the null hypothesis that there is no difference in conflict management styles of compromising and integrating between male and female employees of public banks in Ethiopia. Further, Cohen's effect size value of compromising $(d=.13)$ and integrating $(d=.15)$ suggested small significant difference.

On the other hand, a non- significant result observed for the variables avoiding $t(293)=.928, p \leq .05$, dominating $t(293)=$ $0.118, \quad p \leq .05$ and obliging $t(293)=0.816, p \leq .05$. Therefore, we fail to reject the null hypothesis that there is no difference in conflict management styles of avoiding, dominating and obliging between female and male employees of public banks in Ethiopia.

\section{Discussion}

The main objective of this exploratory study was to determine the impact of gender variable on the preference of conflict management styles of employees of public banks in Ethiopia.

The results of this study clearly supports three out of five hypotheses that no a statistical differences exist in conflict handling styles between Ethiopian public bank employees with regard to gender. First, the study found that gender had significant impact in the use of compromising and integrating conflict management styles. Second, the study found that gender had no significant impact in the use of avoiding, dominating and obliging styles of conflict handling. However, the results of the mean shows that male found to be more integrating, compromising, obliging, avoiding and integrating than females. This study is similar to Sorenson, and Hawkins who found that both males and females were most likely to choose, in order of preference, integrating, followed by compromising [31]. In contrary, Rahim found that woman to be more integrating, avoiding, and compromising and less obliging than men [20].

For conflict management styles of avoiding, obliging and integrating, this study is similar with Shockley-Zalabak and Morley whose findings indicated no significant differences in avoiding, or accommodating modes, whereas significant differences were found for compromising and competing [32]. Furthermore, neither Chusmir and Mills nor Berry found significant differences between the conflict resolution styles of men and women [33], [34]. Similarly, Gayle found no significant relationship between any of the conflict management strategies with respect to sex [35]. These support our findings for conflict management styles of avoiding, dominating and obliging. The lack of a significant difference between gender and conflict management styles of avoiding, dominating and obliging was not surprising. Sex is a socially-prescribed concept in which men are classified as masculine and women are classified as feminine. As a general rule, men can have female or masculine attributes though ladies likewise can have feminine or masculine characteristics. Thus, the absence of significant difference between gender and conflict handling styles of avoiding, dominating, and obliging is expected as grouping every person as having male or female personality characteristics exclusively based upon their sex is inaccurate [36].

To sum up, this study revealed interesting findings about the influence on gender in conflict management styles of employees of public banks in Ethiopia. These findings can be summarized with the following table 4 . 


\section{International Journal of Science and Research (IJSR) \\ ISSN (Online): 2319-7064}

Index Copernicus Value (2013): 6.14 | Impact Factor (2014): 5.611

Table 4: Summary of the hypothesis, techniques and results of the test

\begin{tabular}{|c|l|c|c|}
\hline Hypothesis & \multicolumn{1}{|c|}{ Description } & Technique & $\begin{array}{c}\text { Accept/reject the null } \\
\text { hypothesis }\end{array}$ \\
\hline$H_{1}$ & $\begin{array}{l}\text { There is no statistically significant difference in the preference of } \\
\text { avoiding conflict management styles on the basis of gender. }\end{array}$ & $\begin{array}{l}\text { Independent } \\
\text { sample t-test }\end{array}$ & Accepted \\
\hline$H_{2}$ & $\begin{array}{l}\text { There is no statistically significant difference in the preference of } \\
\text { compromising conflict management styles on the basis of gender. }\end{array}$ & $\begin{array}{l}\text { Independent } \\
\text { sample t-test }\end{array}$ & Rejected \\
\hline$H_{3}$ & $\begin{array}{l}\text { There is no statistically significant difference in the preference of } \\
\text { dominating conflict management styles on the basis of gender. }\end{array}$ & $\begin{array}{l}\text { Independent } \\
\text { sample t-test }\end{array}$ & Accepted \\
\hline$H_{4}$ & $\begin{array}{l}\text { There is no statistically significant difference in the preference of } \\
\text { integrating conflict management styles on the basis of gender. }\end{array}$ & $\begin{array}{l}\text { Independent } \\
\text { sample t-test }\end{array}$ & Rejected \\
\hline$H_{5}$ & $\begin{array}{l}\text { There is no statistically significant difference in the preference of } \\
\text { obliging conflict management styles on the basis of gender. }\end{array}$ & $\begin{array}{l}\text { Independent } \\
\text { sample t-test }\end{array}$ & Accepted \\
\hline
\end{tabular}

\section{Conclusion}

This study provides insights into the influence of gender on conflict management styles of employees of public banks in Ethiopia. In some instances, the results are compelling and consistent with other studies and in other cases, as shown in this study, the findings differ.

It was hypothesized that gender had no impact on conflict management styles of employees, however, the study revealed that only two out of five conflict management styles surveyed are impacted by gender.

Gender was found significantly relate with compromising and integrating conflict management styles of employees. On the contrary, gender was found no significant difference with avoiding, dominating and obliging conflict management styles of employees of public banks in Ethiopia. However, the results of the mean showed that men found to be more integrating, compromising, obliging, avoiding and dominating than females.

In conclusion it can be stated that no studies have been done to examine the impact of gender in conflict management styles of employees of public banks in Ethiopia. It is believed that this study, though exploratory in nature, has given a more usable picture of the relationship between gender and conflict management styles.

\section{Future Research}

The present study sets the stage for researchers to be able to empirically determine the impact of gender on the preference of conflict management styles of employees. Further research should be conducted in order to find other demographic variables that could impact on the choice of conflict management styles of employees. Second, in order to compare conflict management styles, future research should incorporate private banks. Finally, a future study could expand on this study to include public bank managers, and other stakeholders and anyone who falls within their organizational structure.

\section{Limitations}

As with other studies, there were quite few limitations for this study. Firstly, this study have not been incorporated all demographic variables. These excluded demographic characteristics could be included in further studies. Secondly, this study was cross-sectional in nature and does not examine whether individualse conflict handling styles change over time. Hence, future research with a longitudinal survey, with the intention of determining whether a conflict handling style used is changing overtime should be conducted.

\section{References}

[1] Taylor, D.M and Moghaddam, F.M. (1994), Theories of Intergroup Relations. London: Praeger.

[2] Coser, L.A. (1956). The Functions of Social Conflict. Glencoe, Illinois: The Free Press. Cited in Cavanagh, S.J.C. (1991). "The Conflict Management Style of Staff Nurses and Nurse Managers," Journal of Advanced Nursing, 16: 1254-1260.

[3] Mayer B., (2000), The dynamics of conflict resolution, San Fransisco : Jossey- Bass

[4] Rahim, M.A. (2001). Managing Conflict in Organizations (3rd ed.). Westport, CT: Quorum Books.

[5] Roloff, M.E. (1987). "Communication and Conflict," in C. R. Berger and S. H. Chaffee (eds.), Handbook of Communication Science: 484-534. Newbury Park, CA: Sage.

[6] Mayo, E. (1945). The Social Problems of an Industrial Civilization, Cambridge. Massachusetts: Harvard Universitiy Press. Cited in Cavanagh, S.J.C. (1991). "The Conflict Management Style of Staff Nurses and Nurse Managers," journal of Advanced Nursing, 16: 1254-1260.

[7] Kelly, J. (1970). "Make Conflict Work for You," Harvard Business Review, 48: 103-113.

[8] Lewis, J.H. (1976). “Conflict Management," Journal of Nursing Administration. 6: 18-22.

[9] O'Connor, A.B. (1978). "Sources of Conflict for Faculty Members," Journal of Nursing Education, 17(5): 35-38.

[10] Schmidt, W.H. and Tannenbaum, R. (1960). "The Management of Differences," Harvard Business Review. 38: 107-115.

[11]Deutsch, M. (1971). "Towards an Understanding of Conflict," International Journal of Group Tensions. 1: 42-54.

[12] Amason, A.C. (1996). "Distinguishing the Effects of Functional and Dysfunctional Conflict on Strategic Decision making: Resolving a Paradox for Top Management Teams," Academy of Management Journal, 39: 123-148. 


\section{International Journal of Science and Research (IJSR) \\ ISSN (Online): 2319-7064}

Index Copernicus Value (2013): 6.14 | Impact Factor (2014): 5.611

[13] Pondy, L.R. (1992). "Reflections on Organizational Conflict," Journal of Organizational Behavior, 13: 257261.

[14] Wall, J.A. and Callister, R.R. (1995). "Conflict and Its Management," Journal of Management, 21:515-558

[15] Pearson, A.W., Ensley, M.D., and Amason, A.C. (2002). "An Assessment and Refinement of Jehn"s Intra-group Conflict Scale," International Journal of Conflict Management, 13: 110-126.

[16] Rahim, M.A. (2000). "Emprical Studies on Handling Conflict," International Journal of Conflict Management, 11: 5-8.

[17] Rahim, M.A. (2002). "Toward a Theory of Managing Organizational Conflict," International Journal of Conflict Management, 11: 5-8.

[18] Blake, R.R. and Mouton, J.S. (1964). The Managerial Grid. Houston, TX: Gulf Publishing.

[19] Thomas, K.W \& Kilmann, H.R. (1974). Thomas-Kilman Conflict MODE Instrument. New York: Xicom.

[20] Rahim, M.A. (1983). A measure of styles of handling interpersonal conflict. Academy of Management Journal, 26, 368 - 376.

[21] Powell, G.N. (1988). Women and Men in Management. Newbury Park, CA: Sage. Cited in Brewer,

[22] McKenna, S. and Richardson, J. (1995). "Business Values, Management and Conflict Handling: Issues in Contemporary Singapore," Journal of Management Development, 11(4): 56-70.

[23] Bedell, J. and Sistrunk, F. (1973). "Power, Opportunity Costs and Sex in a Mixed-motive Game,"Journal of Personality and Social Psychology, 31: 634-643.

[24] Eagly, A.H. and Johnson, B.T. (1990). "Gender and Leadership Style: A Meta Analysis," Psychological Bulletin," 108: 233-256.

[25] Korabik, K., Baril, G.L., and Watson, C. (1993). "Manager's Conflict Management Style and Leadership Effectiveness: The Moderating Effects of Gender," Sex Roles, 29: 405-420.

[26]Rubin, J.Z. and Brown, B.R. (1975). The Social Psychology of Bargaining Negotiation. New York: Academic Press. Cited in Brewer, N., Mitchell, P. and Weber, N. (2002). "Gender Role, Organizational Status and Conflict Management Styles," International Journal of Conflict Management, 13(1): 78-94.

[27] Gree, B., Brewer, N., Mitchell, P., and Weber, N. (2002). "Gender Role, Organizational Status and Conflict Management Styles," International Journal of Conflict Management, 13(1): 78-94.

[28] National bank of Ethiopia (2012), www.cbb.com.et, accessed March 25, 2014

[29] Yamane, T., 1967. Statistics: An Introductory Analysis, 2nd Ed., New York: Harper and Row

[30] Cohen, J. (1988). Statistical power analysis for the behavioral sciences ( $2^{\text {nd }}$ ed.). Hillsdale: L. Erlbaum Associates

[31] Sorenson, P. and Hawkins, K. (1995). "Gender, Psychological Type and Conflict Style Preference," Management Communication Quarterly, 9: 115-127.

[32] Shockley-Zalabak, P. S., \& Morley, D. D. (1984). Sex differences in conflict style preferences. Communication Research Reports, 1, 28-32.
[33] Chismur, L.H., \& Mills, J. (1989). Gender differences in conflict resolution styles of managers: at work and at home. Sex Roles, 20(3/4), 149-163.

[34] Berry, B. P. (1994). An analysis of the relationship between gender, gender-role classification and interpersonal conflict management styles of selected Missouri school administrators. Doctoral dissertation, St. Louis University. St. Louis, MO.

[35] Gayle, M. B. (1991). Sex equity in workplace conflict management. Journal of Applied Communication Research, 19, 152-169.

[36] Leah, B. (2010). "Organized chaos: A survey of conflict management strategies, gender roles, \& status in an organizational setting". Journal of Undergraduate research XII 